НАУКОВИЙ ВІСНИК

T.

cientific messenger of Lviv National University
Veterinary Meedicine and Bioteclinologies

now

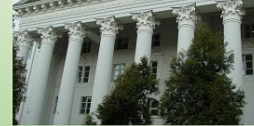

Том 21 № 91

2019
Науковий вісник Дьвівського національного університету ветеринарної медицини та біотехнодогій імені С.3. Гжицького. Серія: Сідьськогосподарські науки

\author{
Scientific Messenger of Lviv National University
} of Veterinary Medicine and Biotechnologies. Series: Agricultural sciences

ISSN 2519-2698 print

https://nvlvet.com.ua/index.php/agriculture

doi: $10.32718 /$ nvlvet-a9114

UDC 631.17: 633: 582.4

\title{
Effectiveness evaluation of energy crops production as a biofuel sources
}

\author{
V.L. Nosko, O.V. Pavliv, A.Iu. Linnik
}

Separated Subdivision of National University of Life and Environmental Sciences of Ukraine "Berezhany Agritechnical Institute”, Berezhany, Ukraine

Article info

Received 13.09.2019

Received in revised form 14.10 .2019

Accepted 15.10.2019

Separated subdivision of National University of Life and Environmental Sciences of Ukraine "Berezhany Agrotechnical Institute”, Academichna Str., 20, Berezhany, Ternopil region, 47501, Ukraine.

Tel.: +38-067-208-60-99

E-mail:kafedra.eo.bati@gmail.com
Nosko, V.L., Pavliv, O.V., \& Linnik, A.Iu. (2019). Effectiveness evaluation of energy crops production as a biofuel sources. Scientific Messenger of Lviv National University of Veterinary Medicine and Biotechnologies. Series: Agricultural sciences, 21(91), 83-88. doi: 10.32718/nvlvet-a9114

Energy crops are grown for energy purposes. Traditionally energy crops are corn and sugarcane which are grown for industrial scale ethanol, rapeseed for producing biodiesel, annual and perennial grasses, for example cane, miscanthus, cereal straw, as well as fast-growing tree crops for biomass production. The most interesting for the temperate climate zone of Europe are the fast-growing willow species. The interest in growing energy crops, which can be used as a renewable energy source, in European countries arose in the 1970s, which was related with rising prices for traditional energy sources. The growth of energy crops has been fueled by political decisions at the international level, in particular by documents such as the Renewable Energy Development Plan for Europe and the Kyoto Protocol. After some recession, landing areas for energy crops in the EU and North America have been stabilized. The fastest growing willow occupies the largest area in Europe. The average yield of willow wood in our experiments was about 50 tons per hectare at a moisture content of $45 \%$, with a three-year biomass harvest cycle or 9.2 tons per year and dry matter from 9 to 15 tons per year per dry biomass, in depending on the conditions of cultivation, soil, clone. The weighted average cost of one ton of willow wood with a moisture content of $10 \%$ at an area of 100 hectares of plantation for its lifetime (22 years) will be \$30.5. The cost of growing willow, transporting and shredding timber at a plantation area of 30 hectares is about $\$ 510$ per hectare. About half of all biofuel production costs are depreciation deductions for the operation of special planting and harvesting equipment. The expansion of the plantation area 3-4 times compared to the base variant (30 hectares) allows to increase the profitability of energy production by 30-50\%. The return on initial costs required to organize a willow plantation depends on the use of biomass. When replacing wood with traditional energy sources (natural gas), according to our calculations, the simple payback period is 3.8 years and the discounted time is 4.7 years, which corresponds to the time of harvesting the first biomass crop. With the direct sale of biomass on the market in the payback period increases to 6-11 years, which corresponds to the second or third harvesting period (with a three-year cycle). The unit cost of energy derived from willow wood is lower relatively to other energy crops, but 1.5 times and 1.8 times higher than that of natural marsh vegetation and straw, respectively. However, the additional interest in planting willow is due to their conservation value. The main indicators for calculating cost-effectiveness have been taken experimentally. The higher combustion heat of the above-ground part of the willow tree stand averaged $18500 \mathrm{~kJ} / \mathrm{kg}$. This is in line with the results obtained by other researchers for willow wood. The maximum specific heat of combustion of willow wood according to the results of experiments carried out in Sweden ranged from 18.3 to $19.7 \mathrm{MJ} / \mathrm{kg}$, depending on the harvesting time and the willow clones. Therefore, we can confidently say that to grow energy willow is expediently and cost-effectively.

Key words: biofuel, energy crops, market, cost price, payback period.

\section{Оцінка ефективності вирощування енергетичних культур як джерело біопалива}

В.Л. Носко, О.В. Павлів, А.Ю. Ліннік 
Відокремлений підрозділ Національного університету біоресурсів $і$ природокористування Украӥни “Бережанський агротехнічний інститут”, м. Бережани, Украйна

Енергетичні культури вирощуються для енергетичних потреб. Традииійно енергетичними культурами є кукурудза і иукровий очерет, які вирощуються для виробництва етанолу в промислових масштабах, ріпак для отримання біодизеля, однорічні та багаторічні трави: наприклад, очерет, міскантус, солома зернових культур, а також швидко зростаючі деревні культури для виробництва біомаси. Для помірного кліматичного поясу Європи найбільший иікавість представляють швидкорослі види верби. Цікавість до вирощування енергетичних культур, біомаса яких може бути використана як відновлювальне джерело енергії, в європейських країнах виник в 70-ті роки минулого століття, щь було пов'язано з ростом иін на традиційні енергоносії. Зростання площ енергетичних культур стимулювався політичними рішеннями на міжнародному рівні, зокрема такими документами як План розвитку відновлюваної енергетики в Європі та Кіотський протокол. Після певного спаду, площі посадок енергетичних культур в країнах ЄС та Північної Америки стабілізувалися. Найбільш значні площі в Свропі займає швидкозростаюча верба. Середня врожайність деревини верби в наших експериментах склала близько 50 тонн з гектара при вологості 45\%, при трирічному циклі збору біомаси або 9,2 тонни в перерахунку на рік і на суху речовину від 9 до 15 тонн на рік в перерахунку на суху біомасу, в залежності від умов вирощування, трунту, клону. Середньозважена собівартість однієї тонни деревини верби вологістю $10 \%$ при площі енергетичної плантачії 100 га за термін ії експлуатації (22 роки) складе 30,5 долара. Витрати на вирощування верби, транспортування і подрібнення деревини при площі плантаиії 30 гектарів складають близько 510 доларів в розрахунку на гектар. Близько половини всіх витрат на виробництво біопалива складають амортизачійні відрахування на експлуатацію спеціальної посадкової $i$ збиральної техніки. Розширення площ плантації в 3-4 рази в порівнянні з базовим варіантом (30 гектар) дозволяє збільшити рентабельність виробництва енергї на 30-50\%. Окупність початкових затрат необхідних для організачії плантачії верби залежить від напрямів використання біомаси. При заміні деревиною традиційних енергоносіїв (природний газ) за нашими розрахунками простий термін окупності становить 3,8 року і дисконтований - 4,7 року, що відповідає часу збирання першого врожаю біомаси. При безпосередньому продажі біомаси на ринку в термін окупності збільшується до 6-11 років, що відповідає другому або третьому терміну збирання (при трирічному ииклі). Собівартість одинииі енергії отриманої з деревини верби, нижче по відноменню до інших енергетичних культур, але в 1,5 рази та в 1,8 рази вище, ніж відповідно з біомаси природного болотної рослинності $i$ соломи. Тим не менш, додатковий інтерес до посадки верби обумовлюється їх природоохоронним значенням. В якості основних показників для розрахунку економічної ефективності приймалися результати, отримані експериментальним шляхом. Вища теплота згоряння надземної частини деревостану верби в середньому склала 18500 кДж/кг. Це відповідає результатам, отриманим для деревини верби іншими дослідниками. Максимальна питома теплота згоряння деревини верби за результатами експериментів проведених в Швеції склала від 18,3 до 19,7 МДж/кг, в залежності від строків збирання і клонів верби. Отже, можемо з впевненістю стверджувати, що енергетичну вербу, вирощувати доцільно і економічно вигідно.

Ключові слова: біопаливо, енергетичні культури, ринок, собівартість, період окупності.

\section{Вступ}

Енергетичні культури вирощуються для енергетичних потреб. Традиційно енергетичними культурами $\epsilon$ кукурудза і цукровий очерет, які вирощуються для виробництва етанолу в промислових масштабах, ріпак для отримання біодизеля, однорічні та багаторічні трави: наприклад, очерет, міскантус, солома зернових культур, а також швидко зростаючі деревні культури для виробництва біомаси. Для помірного кліматичного поясу Європи найбільший цікавість представляють швидкорослі види верби і тополі, залишки зернових культур, міскантус, очеретянка, ріпак. Кожна 3 цих культур має свої особливості з точки зору типу біопалива, умов вирощування, вимог до екологічних факторів і т.д. Комерційні плантації енергетичних культур в Європі з'явилися в 70-і роки минулого століття, що було пов'язано як зі зростаючим інтересом суспільства до екологічних проблем в цілому, так і зростанням цін на традиційні енергоносії.

Різкий стрибок цін з 1970 по 2019 роки стимулював пошук альтернативних варіантів для енергозабезпечення, особливо в країнах, що не мають в наявності власних ресурсів у достатній кількості. Підписання Кіотського протоколу (1997 рік) зумовило подальший інтерес до відновлюваної енергетики, в значній мірі пов'язаний $з$ необхідністю скорочень викидів парникових газів і перспективи отримання вуглецевих кредитів. Таким чином, з економічної точки зору визначальним стимулом для використання енергетичних культур, так само як і інших джерел відновлюваної енергії $є$ ціна на нафту.
Введенням в 1991 році нової сільськогосподарської політики в Швеції, яка була орієнтована на зниження цін на зерно і зростання субсидій для вирощування енергетичних культур;

- Зростанням податків на викопне паливо;

- Розвитком ринку біопалива в Швеції і в Свропі (European Commission, 1997).

Як результат, за 10 річний період, з 1991 по 2001 рік, площі плантацій верби 3 майже нульового рівня досягли 20000 гектарів. Такий динаміці сприяв план розвитку відновлюваної енергетики в Свропі, прийнятий в 1997 році. Відповідно до нього, частка біоенергетики в загальному обсязі енергоспоживання повинна була вирости від 3 до 8,5\%, при цьому половина зростання планувалося забезпечити за рахунок енергетичних культур. Вищезгаданий План так само зумовив інтерес до енергетичного використання біомаси трав і соломи. Зокрема, в Ірландії, Польщі та інших країнах збільшилася площі посівів міскантусу (Energy 21 the Danish government's action plan for energy, 1996).

У Данії основний акцент був зроблений на використання в якості біопалива соломи зернових культур, де щорічно на ці цілі використовується понад 1,3 млн тонн (Wichtmann \& Wichmann, 2011).

Інноваційним напрямком розвитку біоенергетики стало використання в енергетичних цілях біомаси болотних рослин, очерету і очеретянка. Цей напрямок одержав назву “палудікультура”, що можна приблизно перекласти як затоплене сільське і лісове господарство. 
Різке падіння ціна на традиційні енергоносії, в останні роки негативно позначилося на перспективах використання біопалива. Проте, площі посадок енергетичних культур, серед яких переважають плантації швидкозростаючої верби, залишаються в останні роки досить стабільними.

Питання економічної ефективності виробництва біомаси, розглядалися в ряді робіт зарубіжних дослідників, починаючи з моменту зародження ринку біопалива (Helby, 2004). Найбільш масштабні досліджень 3 оцінки собівартості біопалива отриманого на основі ряду енергетичних культур проведено в Швеції. Результати досліджень підтверджують економічну ефективність плантацій верби в порівнянні 3 іншими енергетичними культурами. При сформованих економічних і ринкових умовах найбільш низька собівартість мала місце для верби - 4-5 Євро за ГДж, собівартість енергії виробленої з біомаси тополі склала 5-5-

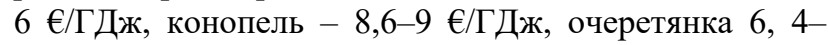
$7 € /$ Дж, міскантусу - 7,9-8,45 €/ГДж, тритикале 6,7-7,1 €/ГДж. Krasuska Е. i Rosenqvist Н. вивчали економічні аспекти використання верби, міскантусу i тритикале на енергетичні цілі в умовах Польщі (Krasuska \& Rosenqvist, 2012). Встановлено, що при сформованих в країні умовах ринку сільськогосподарської продукції, більш висока рентабельність характерна для виробництва одиниці енергії з деревини верби. Автори відзначають, що в умовах нестабільності цін на ринку зерна, енергетичні культури є цілком конкурентоспроможними по відношенню до зернових культур.

Починаючи з 90-х років минулого століття, площі плантацій енергетичних культур стали рости в США і Канаді, чому сприяла енергетична політика держав, спрямована на виділення додаткових субсидій. У Канаді північних і центральних штатах США основний акцент був зроблений на вирощування верби і в південних штатах - тополі. За результатами досліджень було розроблено математичну модель, яка дозволяє оцінити собівартість і рентабельність виробництва біомаси (Rod'kin et al., 2014).

Основною метою наших досліджень представлених в рамках даної статті, є оцінка доцільності вирощування енергетичних культур для виробництва біомаси в умовах держави.

\section{Матеріал і методи досліджень}

Дослідження 3 оцінки ефективності виробництва різних видів біомаси (деревина верби, солома зернових культур, біомаса багаторічних трав) на енергетичні цілі проводилися в перебігу ряду років на експе- риментальних ділянках Бережанського Агротехнічного Інституту.

Енергетичні плантації верби вирощуються з 2012 року на дерново підзолистих грунтах, які є характерні для Західного Лісостепу України). Для розрахунку економічної ефективності використовувалася інтерактивна модель, розроблена за результатами досліджень (Gusakov, 2005).

Розрахунок економічної ефективності використання соломи зернових культур на енергетичні цілі проводилися на базі господарств Львівської та Тернопільської областей. Технологія обробітку зернових відповідала нормативним вимогам для кліматичної зони Західного Лісостепу України. На основі технологічної карти розроблена інтерактивна модель для розрахунку економічних показників (But'ko et al., 2015).

Дослідження за оцінкою продуктивності природних багаторічних трав проводилися на вироблених торфовищах підприємства ПОП “Урманське”, ПрАТ “Львівський Облрибкомбінат”.

Розрахунок собівартості проводився на основі схеми виробничої системи життєвого циклу біомаси складається 39 основних одиничних процесів.

Для розрахунку собівартості одиниці енергії, яку можна отримати з біомаси деревини, соломи зернових культур і багаторічних трав проводилися вимірювання питомої теплоти згорання (Styles \& Jones, 2007).

\section{Результати та їх обговорення}

В якості основних показників для розрахунку економічної ефективності приймалися результати, отримані експериментальним шляхом. Вища теплота згоряння надземної частини деревостану верби в середньому склала 18500 кДж/кг. Це відповідає результатам, отриманим для деревини верби іншими дослідниками. Максимальна питома теплота згоряння деревини верби за результатами експериментів проведених в Швеції склала від 18,3 до 19,7 МДж/кг, в залежності від строків збирання і клонів верби (Styles et al., 2008).

Середня врожайність деревини верби в наших експериментах склала близько 50 тонн 3 гектара при вологості 45\%, при трирічному циклі збору біомаси або 9,2 тонни в перерахунку на рік і на суху речовину від 9 до 15 тонн на рік в перерахунку на суху біомасу, в залежності від умов вирощування, грунту, клону і Т.д.

Показники вологості деревини верби при збиранні, згідно з експериментальними даними, отриманими в різних екологічних умовах, коливалися від 45\% до 50\% (Ledin, 1996).

\section{Таблиця 1}

Економічна ефективність виробництва та доопрацювання деревини верби на штучних плантаціях

\begin{tabular}{lccccc}
\hline \multicolumn{1}{c}{ Технологія } & $\begin{array}{c}\text { Площа посадки, } \\
\text { га }\end{array}$ & $\begin{array}{c}\text { Затрати на } \\
\text { гектар, } \$\end{array}$ & $\begin{array}{c}\text { Урожайність з гектару в рік } \\
\text { (на 10\% вологість) }\end{array}$ & $\begin{array}{c}\text { Прибуток } \\
\text { Прибуток з } \\
\text { Гектару, \$ }\end{array}$ \\
\hline Промислова & 30 & 510 & 12 & 858 & 348 \\
без сушки & 100 & 365 & 12 & 858 & 493 \\
\hline
\end{tabular}


Економічна ефективність чи рентабельність виробництва верби залежать від їі собівартості і вартості реалізації. Як показали наші розрахунки, собівартість виробництва біомаси в значній мірі залежить від площі плантації.

Витрати на вирощування верби, транспортування i подрібнення деревини при площі плантації 30 гектарів складають близько 510 доларів в розрахунку на гектар. Близько половини всіх витрат на виробництво біопалива складають амортизаційні відрахування на експлуатацію спеціальної посадкової і збиральної техніки, що пов'язано з їі високою вартістю і вузькою спеціалізацією. Розширення площ плантації в 3-4 рази в порівнянні з базовим варіантом (30 гектар) дозволяє збільшити рентабельність виробництва енергії на 30-50\%. Одним 3 найважливіших економічних показників для виробника є період (строк) окупності капіталовкладень - час, протягом якого амортизація і суми чистого прибутку спрямовуються на повернення інвестованого капіталу.

Найбільш значні грошові кошти необхідно вкласти протягом перших 4 років від моменту закладки плантації. До посадки верби повинні бути проведені роботи з підготовки грунту, придбані мінеральні добрива і гербіциди, посадковий матеріал і посадкова машина. Найсерйозніші капіталовкладення необхідні на 4 рік від часу посадки плантації, та з придбанням збиральної техніки. Вартість комбайна становить від 150 тисяч доларів (BenderMark, виробництво Швеція), (Biobaler, виробництво Канада) до 300 тисяч доларів (CaseNewHolland, виробництво Бельгія). Комбайни BenderMark i Biobaler це вузькоспеціалізована техніка, призначена для збирання деревини (верба або інші культури), тому амортизаційні відрахування при використанні такої техніки безпосередньо залежать від площі плантації. Комбайн CaseNewHolland може так само використовуватися, наприклад, для скошування кукурудзи, і для збирання деревини він повинен бути оснащений спеціальним посиленим змінним хедером 130 FB. Недолік комбайна у високій вартості, перевага в більш широкої спеціалізації, що передбачає кращу ефективність використання. Конкретний вибір залежить від спеціалізації господарства, фінансових можливостей i інших умов. Розрахунковий термін експлуатації плантації верби становить 22 роки від моменту посадки, що обумовлюється кількістю циклів збирання врожаю деревини. Встановлено, що врожайність деревини верби залишається досить стабільною величиною протягом 7 циклів вирощування, при трирічному періоді часу між скошуванням біомаси. При подальшої експлуатації плантації врожайність буде знижуватися.

Витрати необхідні протягом перших 4 років експлуатації плантації верби при площі 100 гектарів, за нашими розрахунками складають близько 3200 доларів на гектар. Ці дані можна порівняти з показниками, наведеними для умов штату Нью-Йорк (США). Середнє для штату Нью-Йорк початкове інвестування необхідне для закладки енергетичної плантації верби становить 3097 доларів на гектар, включаючи фінанси необхідні власне для плантації 2709 доларів на гектар, вартість оренди землі 340 доларів на гектар і адмініс- тративні витрати - 48 доларів на гектар (Styles \& Jones, 2007). При цьому, в структурі витрат в порівнянні з умовами України, більш значна частка припадає на оренду землі і заробітну плату. I навпаки, істотно нижче амортизаційні відрахування на експлуатацію техніки, так як площі комерційних плантацій верби тільки в штаті Нью-Йорк становлять кілька тисяч гектарів. Науковий журнал НДУ ITMО. Серія “Економіка і екологічний менеджмент” № 4, 2016106

Окупність інвестицій може бути розрахована в залежності від планів подальшого використання біомаси виробником. Якщо використовувати біопаливо на власні потреби, то його можна розглядати як заміну традиційним енергоносіям, в першу чергу природного газу. Як не дивно, падіння цін на викопне паливо на світовому ринку мало позначилося на цінах для конкретних споживачів, юридичних і фізичних осіб. Ціни на природний газ для юридичних осіб в Україні складають від 160 до 280 доларів в еквіваленті за $1000 \mathrm{~m}^{3}$, в залежності від категорії. 3 одного гектара плантації верби можна отримати 16,7 тонн деревини в розрахунку на рік, що за питомою теплотою згоряння еквівалентно 3,9 тис.м ${ }^{3}$ природного газу. При усередненої вартості однієї тисячі м $^{3}$ газу для юридичних осіб 220 доларів, при його заміні на деревне паливо потенційна виручка з гектара плантації складе не менше 858 доларів гривень за рік (таблиця 1).

Простий термін окупності є період, протягом якого чистий потік готівки (ЧПГ) наростаючим підсумком досягне позитивної величини. При заміні деревиною природного газу, простий термін окупності початкових інвестицій складе 3,8 року, це означає, що витрати окупляться вже першим урожаєм біомаси верби.

Дисконтований термін окупності це період повернення грошових коштів 3 урахуванням тимчасової вартості грошей (ставки дисконту).

Якщо прийняти за основу поточну процентну ставку Національного банку України, період окупності за умови заміщення деревиною природного газу збільшиться до 4,7 року.

Ринок біопалива, в Україні є вкрай нестабільним фактором. Як показує аналіз, ціна на деревну тріску з вологістю $30-40 \%$ в середньому становить близько 30-40 доларів в еквіваленті. Простий термін окупності початкових інвестицій при реалізації деревини на ринку за цими цінами складе відповідно 7,9 і 5,9 років, і дисконтований 11,1 і 7,3 року. Для фермерів США, рентабельність отримання біомаси верби без додаткових субсидій становить близько 10\% (Rod'kin et al., 2014). У цьому випадку термін окупності плантації складе 3-4 періоду збирання врожаю або 1014 років. Для підтримки виробників біомаси верби в країні здійснюється виділення цільових субсидій для стабілізації ринкової вартості на рівні 60 доларів за тонну умовно сухої деревини, що дозволяє збільшити рентабельність до 20\%, 3 періодом окупності 48 років, що є конкурентоспроможними по відношенню до традиційних культур, наприклад зерновим або кукурудзі.

Середньозважена собівартість однієї тонни деревини верби вологістю 10\% при площі енергетичної 
плантації 100 га за звістку термін іiі експлуатації (22 роки) складе 30,5 долара. Аналогічним чином розраховувалася собівартість біомаси соломи і приро- дних багаторічних трав, як інших потенційних джерел енергії в агроландшафтах. Порівняльні характеристики біомаси представлені в табл. 2.

\section{Таблиця 2}

Собівартість однієї тонни біомаси з деревини верби, соломи та природної болотної рослинності

\begin{tabular}{lcccc}
\hline \multicolumn{1}{c}{ Види біомаси } & Вологість, \% & Ступінь подрібнення, мм & Урожайність, т/га & Собівартість за тону, \$ \\
\hline Деревина верби & 10 & До 5 & 12 & 30,5 \\
Солома & 14 & Не подрібнювати & 3 & 9 \\
Сіно & 14 & До 5 & 15,3 & 14 \\
\hline
\end{tabular}

Характеристика і собівартість видів біомаси представлених в таблиці 2 отримані на основі результатів експериментальних досліджень з урахуванням рекомендацій щодо подальшої технології використання біомаси в енергетичних цілях. Біомасу соломи доцільно використовувати для безпосереднього спалювання в твердопаливних котлах і отримання теплової енергії. Біомасу багаторічних трав, зі ступенем подрібнення до 5 мм, раціонально використовувати для приготування пелет і (або) додавання в торфобрикети. Біомасу деревини верби можна використовувати як безпосередньо для спалювання і отримання теплової енергії, так і виготовлення пеллет і торфобіобрикетів. Для коректної порівняльної оцінки, розрахунки повинні грунтуватися на уніфікованих характеристиках біомаси, з урахуванням питомої теплоти згорання. Результати розрахунків собівартості біомаси деревини верби, соломи та болотної рослинності при рівних показниках вологості, і ступеня подрібнення, а так же енергії, яка може бути отримана при спалюванні біомаси в залежності від теплоти згорання, представлені в табл. 3. Найбільш висока питома теплота згоряння біомаси була у деревині верби, солома в свою чергу дещо перевищує за цим показником сіно болотної рослинності. Таким чином, собівартість одиниці енергії отриманої з деревини верби в 1,5 рази і в 1,8 рази вище, ніж відповідно з біомаси природною болотної рослинності і соломи, що відповідає даним зарубіжних дослідників (Styles et al., 2008). У представлених розрахунках собівартості соломи не враховувалися витрати пов'язані з посівом, доглядом і збиранням зернових культур. Солома приймалася до уваги як рослинний залишок, який можна використовувати на енергетичні цілі.

\section{Таблиця 3}

Собівартість одиниці енергії отриманої з біомаси деревини верби, соломи зернових культур і сіна болотної рослинності

\begin{tabular}{lccccc}
\hline \multirow{2}{*}{ Біомасса } & \multirow{2}{*}{ Вологість, \% } & $\begin{array}{c}\text { Ступінь подрібнення, } \\
\text { мм }\end{array}$ & $\begin{array}{c}\text { Теплота згоряння, } \\
\text { кДж/кг }\end{array}$ & $\begin{array}{c}\text { Собівартість } \\
\text { біомаси за тону, \$ }\end{array}$ & $\begin{array}{c}\text { Собівартість одиниці } \\
\text { енергії, \$/гДж }\end{array}$ \\
\hline Деревина & 10 & До 5 & 18500 & 30,5 & 1,64 \\
Солома & 10 & До 5 & 16000 & 14,4 & 0,9 \\
Сіно & 10 & До 5 & 15500 & 16,4 & 1,09 \\
\hline
\end{tabular}

Сіно отримано з природної болотної рослинності, що так само виключає статті витрат пов'язані з обробітком багаторічних трав. Незважаючи на більш високу собівартість деревини верби в порівнянні з іншими видами біомаси, слід враховувати, що енергетичні плантації верби можуть бути закладені на площах, де немає можливості отримати високий урожай соломи зернових або сіна природних травостоїв 3 екологічних або економічних причин.

\section{Висновки}

Аналіз динаміки виробництва біомаси енергетичних культур за кордоном показує, що площі посадок передбачувано залежать від цін на традиційні енергоресурси. Різкий стрибок цін в 70-х роках минулого століття стимулював інтерес виробників до розширення площ енергетичних культур, що так само підтримувалося енергетичної та екологічної політикою на міжнародному рівні: прийняттям Плану розвитку відновлюваної енергетики в Європі і підписанням Кіотського протоколу. Найбільш значні площі серед енергетичних культур в європейських країнах припадають на плантації коротко циклової посадок верби, площі якої після деякого падіння на початку 21 тисячоліття стабілізувалися, що головним чином пояснюється порівняно низькою собівартістю. Період окупності коротко циклової посадок верби на енергетичні цілі залежить від умов використання. У разі заміщення деревиною природного газу, що доцільно при іiі використанні виробниками на власні потреби, при сформованих в Україні цінах, простий період окупності початкових і основних капіталовкладень в плантацію верби складе 3,8 року і дисконтований - 4,7 року. При реалізації деревини на вкрай нестабільному ринку біопалива, простий період окупності складе 5,9 років (при ціні 40 доларів) за тонну і 7,9 років (при ціні 30 доларів за тонну), дисконтований відповідно 7,3 і 11,1 року. У зарубіжних країнах, стабільність ринку біопалива підтримується за рахунок субсидій, що забезпечує термін окупності деревини верби, наприклад, в США протягом 4-8 років, при їі ринкової вартості 60 доларів за тонну. Собівартість одиниці енергії отриманої з деревини верби, нижче по відно- 
шенню до інших енергетичними культурами, але в 1,5 рази і в 1,8 рази вище, ніж відповідно з біомаси природною болотної рослинності і соломи. Проте, слід враховувати природоохоронне значення посадок верби і те, що енергетичні плантації цієї культури можуть бути закладені на площах, де немає можливості отримати високий урожай соломи зернових або сіна природних травостоїв з екологічних або економічних причин.

\section{References}

But'ko, A.A., Rod'kin, O.I., Pashinskij, V.A., \& Krstich, B. (2015). Ocenka jekologicheskih i tehnologicheskih as-pektov ispol'zovanija rastitel'nyh ostatkov zernovyh i tehnicheskih kul'tur dlja poluchenija jenergii. Vesnik Vicebskaga dzjarzhay̆naga y̆niversitjeta, 2-3(86-87), 41-46 (in Russian).

Energy 21 the Danish government's action plan for energy (1996). Danish Ministry of Environment and Energy, Copenhagen.

European Commission. Energy for the Future: Renewable Sources of Energy. White Paper for a Community Strategy and Action Plan. Communication from the Commission COM(97)599 (1997). Brussels.

Gusakov, V.G. (2005). Organizacionno-tehnologicheskie normativy vozdelyvanija sel'skohozjajstvennyh kul'tur: sbornik otraslevyh reglamentov. In. agrar. jekonomiki NAN Belarusi. Bel. Nauka (in Russian).

Helby, P. (2004). Market development problems for sustainable bio-energy in Sweden. Environmental and Energy System Studies. Report no. 38, the BIOMARK project, Lund.
Krasuska, E., \& Rosenqvist, H. (2012). Economics of energy crops in Poland today and in the future. Biomass and bioenergy, 38, 23-33. doi: 10.1016/j.biombioe.2011.09.011.

Ledin, S. (1996). Willow wood properties, production and economy. Biomass and Bioenergy, 11(2/3), 75-83. doi: 10.1016/0961-9534(96)00022-0.

Rod'kin, O.I., Ivanjukovich, V.A., \& Shabanov, A.A. (2014). Planirovanie proizvodstva biotopliva iz drevesiny bystrorastushhej ivy na osnove interaktivnoj modeli. Vesnyk Vycebskaga dzjarzhawnaga wnyversytjeta, 2(80), 39-44. https://lib.vsu.by/xmlui/ handle/123456789/3304 (in Russian).

Rosenqvist, H., Roos, A., Ling, E., \& Hektor, B. (2000). Willow growers in Sweden. Biomass and Bioenergy 18(2), 137-145. doi: 10.1016/S09619534(99)00081-1.

Styles, D., \& Jones, M.B. (2007). Current and future financial competitiveness of electricity and heat from energy crops: A case study from Ireland. Energy Policy, 35(8), 4355-4367. doi: 10.1016/j.enpol.2007.02.035.

Styles, D., Thorne, F., \& Jones, M.B. (2008). Energy crops in Ireland: An economic comparison of willow and Miscanthus production with conventional farming systems. Biomass and bioenergy, 32(5), 407- 421. doi: 10.1016/j.biombioe.2007.10.012.

Wichtmann, W., \& Wichmann, S. (2011). Environmental, Social and Economic Aspects of a Sustainable Biomass Production. Journal of Sustainable Energy \& Environment Special Issue, 2011, 77-81. http://www.thaiscience.info/Journals/Article/JOSE/10 977091.pdf. 